\title{
Moderately Differentiated Hepatocellular Carcinoma
}

National Cancer Institute

\section{Source}

National Cancer Institute. Moderately Differentiated Hepatocellular Carcinoma. NCI

Thesaurus. Code C96790.

A hepatocellular carcinoma characterized by the presence of malignant cells with abundant eosinophilic cytoplasm forming trabecular and pseudoglandular patterns. It is usually associated with tumors that are larger than $3 \mathrm{~cm}$ in diameter. 